\title{
A TWENTIETH CENTURY VIEW OF CHRIST
}

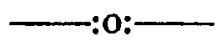

[The following article is translated verbatim, by permission, from a new encyclopædia published in Cairo, of which one-half has already appeared. It is entitled " Dai'ret ul Ma'arif al Karn al 'Asherin," or "Encyclopedia of the Twentieth Century." The work is remarkable, not because of its originality but as representing the thought of the educated young Egyptian. Many of the articles are translations from the best French and English encyclopædias. We are glad to give our readers the translation of the article 'Isa-the Moslem Christ. The author formerly belonged to the nationalist party, and was a warm friend of Mustafa Pasha Kamil, the originator of the movement. Later on he was editor of $A l$ Lewa.-EDITor.]

Jesus, the son of Mary (upon whom be peace), is one of the Apostles of constancy whom God sent to the Children of Israel about nineteen hundred years ago. $\mathrm{He}$ was born in the village of Bethlehem, Palestine, 4004 A.M. according to the Jews, and on the 25th of December A.D. 1, according to Christians. His mother gave birth to Him in a miraculous manner, as $\mathrm{He}$ had no father, for God sent her the holy angel Gabriel (on whom be peace), and he appeared to her in the form of a noble youth, and when she shrank back from him in fear he gave her good tidings, for he had come to grant her a pure boy. And then God breathed into her womb of His spirit and she conceived without human instrumentality. The fœtus grew and was born as other children are born; and when she was delivered of the child her people were suspicious of her conduct. Therefore God made Jesus to speak from His cradle and say to those who were angry, "Verily I am the servant of God who gave me the book and made me a Prophet; and peace be upon me the day I was born and the day I shall die and the day I shall be restored to life."

When Jesus grew up and was strong to receive His message, God sent Him to the Children of Israel, even as He himself testified, "Verily I am sent to the lost sheep of Israel"; and He experienced from them what every 
Apostle experiences from his people, namely, hostility and opposition, and none followed Him save a few people from among the poor and humble, but His teaching concerning the ascetic life and the principles of His wisdom were the cause of grief and pain to the leaders of religion among the Jews. For it is well-known that such leaders and guides hate reformers because they compel them to change the condition of affairs, so that some are brought low and others are elevated, and so the position of those who seek eminence and prestige is lost. Therefore the chiefs of the Jewish religion were incited against Him and accused Him with many false accusations, so that a decree went forth from the Roman Government for His crucifixion, and when they attempted to execute the decree God delivered Him from their hands by raising Him up to Himself; and the commentaries differ among themselves concerning the significance of God's Word (i.e., the Koran), "But God raised Him to Himself." For some of them say that it means $\mathrm{He}$ raised Him up to heaven in bodily form; others say $\mathrm{He}$ made Him to die as men die and then raised His spirit to heaven, in accordance with the other Koran passage, "Verily I will cause Thee to die and raise Thee to Myself."

And those who say that He was raised both in body and in soul explain the passage on causing Him to die, by sleep, even as in some other verses of the Koran the same word here used signifies sleep-i.e., "He will cause you to die in the night" ; that is, he makes you to lose consciousness in sleep.

Christ was indeed raised up (on Him be peace), but the lofty spirit with which He inspired His companions was not taken away with Him. They continued to follow in His footsteps in spite of the wrath of their enemies and the evil that lay in their power, nor did they mind bodily suffering or persecution, but they continued to invite men to their religion, and a great multitude followed them of those whose minds were opened by God to the true direction in the midst of Roman idolatry, even the nations that were in the darkness of superstition. Then the Government began to persecute them 
with fire and iron and every kind of persecution, but this only made them more steadfast in the truth and more earnest in their mission. Nor did this sad condition of affairs cease for nearly three centuries until the time of the Emperor Constantine, who was a Christian. $\mathrm{He}$ it was who commanded the destruction of heathen temples and compelled men to enter the Christian religion by the sword. Then they embraced Christianity by troops and brought into it also their hereditary heathen superstition. It was very difficult for them to strip themselves of these beliefs radically because they were so firmly attached to them. Consequently they mixed them up with their new religion, and this was the first and great corruption that took place in this religion from its original purity. They began to introduce new interpretations of the text and to enlarge the number of sacred books. Traditions and interpretations multiplied, as happened to all other religions in the past, until the seal of the prophets, Mohammed (may God pray for him and give him peace), came with the great reformation of all previous religions, bringing to agreement the beliefs of the various nations and uniting the minds of the people to establish humanity upon the foundations of brotherhood and sincere love, so that the tribes of the human race might know the truth instead of denying it in every way and form.

This is what Moslems teach. As for the Christians, they say that Jesus is the Son of God, conceived by the Virgin Mary by means of the Holy Spirit, that He was born in the village of Bethlehem at the time of the twelfth consulate of Augustus, Emperor of Rome, in the year 4004 from the creation of the world, on December 25th ; and that Joseph, the carpenter, and Mary, travelled with Him to Egypt to escape from the massacre which Herod planned. That they abode in Egypt during the time of the reign of this Roman Emperor [sic], but for fear of the oppression of Archelaus they did not return to Judea but went to Nazareth of Galilee. And when Jesus was twelve years old they came with Him to Jerusalem to the Passover feast. There He remained in the temple and they did not know of it. When they 
returned to seek for Him they found Him in the midst of a company of scribes of the Jews arguing with them concerning religious questions and setting forth the truth by strong and clear arguments.

And when it was the fifteenth year of the reign of the Emperor Tiberius, John the Baptist came-he is the same as Yahya (on whom be peace)-on the banks of the Jordan preaching to men and calling them to repentance, and baptizing them and proclaiming the near appearance of the Messiah. Jesus, therefore, came to him to be baptized at his hands, and he baptized Him; and while Jesus was coming out of the river the Holy Spirit came down upon Him in the form of a dove. Then John declared openly to men that Jesus was the promised Messiah of their sacred books whom the Jews were expecting. Now when Jesus knew that $\mathrm{He}$ was the Messiah He went into the desert and fasted there for forty days to purify Himself and to save Himself from the power of the devil. Then $\mathrm{He}$ returned and went about the country of Judea and Galilee carrying to men the good news of the Kingdom, namely, that the Messiah had appeared, and the manifestation of the forgiveness of God for sinners. He also began to call men to accept His teachings and His offices, emphasising His call by marvellous miracles, such as curing those that were born blind and lepers, and raising the dead and casting out evil spirits from the bodies of those who were possessed. And when many followed $\mathrm{Him} \mathrm{He}$ chose from among them twelve disciples who should go into the world and call men to Hin. In the fourth year of His ministry he appeared in Jerusalem for the last time. His message had aroused the opposition of the rulers of the Jews and the Pharisees. The Pharisces were a party of the Jews who outwardly appeared to be very pious but concealed under this cloak all manner of iniquity.

Nevertheless Jesus went to Jerusalem with His disciples and fulfilled His prayer with them. Then the Jews took Him and led Him to their high priest and then to Pontius Pilate, the governor of Judea on behalf of the Romans. So Jesus was judged and condemned to scourging, punishment, and crucifixion, and the sentence 
was passed upon Him. And when He died the heavens became darkened and the earth shook with an earthquake and the veil of the temple was rent and the graves were opened. And three days after His death Jesus was restored to life and appeared to His disciples and gave them His last instructions and promised them that they would be His successors in the highest offices.

This is what Christians say concerning the birth of Jesus, His origin and His offices in the world; but there are also historical sources, Jewish and Pagan, which do not agree with the Christian sources here followed in regard to His life in the matter of His being the Son of God and being born without a father and the period of His life and the loftiness of His station, but we do not wish to go back to these two sources because they are not altogether trustworthy. For there is no doubt that if the Arabs of the times of ignorance had recorded their histories that the enemies of Islam would have found opportunity to write down as contemporaries of Mohammed (may God bless him) that which would attack Islam and its Prophet, but it would not be fair to give credence to any such records. The most evident proof we have that Jesus (upon Whom be peace) was one of the leading prophets and that $\mathrm{He}$ was perfect in His conduct and pure in His life just as were all the apostles before Him, is this, that His closest companions did not witness in Him save that which produced love for Him and utter confidence in His principles, and the endurance of bitterest persecution and death in patience in accordance with His example. And if these facts do not testify to the integrity of life and the truthfulness of the mission of Jesus, then it is impossible to accept evident proof for anything whatever.

But the learned criticism of Europe has tried to establish that the belief in the deity of Jesus goes back to ancient beliefs, for many of the Pagan nations of antiquity, Persians, Hindoos, Assyrians, Babylonians, Medians and Lydians, asserted the divinity of individuals among them solely for their glorification, just as some among the Moslems have gone so far as to declare the divinity of Mohammed or the divinity of "Ali Ibn Abi 
Mutalib and even of some of their descendants. And as regards Ali, he severely punished those who asserted it with various kinds of punishment, so that he even commanded that some of them be burned alive. But this had no effect upon them, for when he died this particular sect said he was taken up to heaven even as Christ was. Then the sect spread in the first and second centuries of the Hegira, and even to this day there is a remnant existing in Persia.

And among those who have treated the life of Christ critically is Dr. Strauss, for he wrote a book entitled "The Life of the Messiah," in which he offers the theory that Jesus belongs to the mythological characters and had no real existence, the fact being that the sect of Christians when it arose in the first century agreed to write of a perfect character in which they combined all the attributes of perfection, and they named it the Christ, and so the story of His life arose. And among the most extravagant critics of the life of Christ (upon Whom be peace) is M. Merone [?], a Swiss writer, who wrote a book entitled "Christ Estimated at His True Value," in which he asserts that the life of Jesus is not free from suspicion nor His character from moral delinquency, and he expresses his surprise that men should be carried away to worship Him, having neither seen Him or witnessed His work. And he claims that Socrates, the Grecian philosopher who was condemned to drink the poison because of his lofty philosophical teaching was more noble than Christ Himself, for when the poison was given to him to drink he drank it smiling, and the terror of death did not shake him from his constancy. Christ, however, this writer says, according to the Gospels, showed His chagrin at the judgment passed upon Him, and He suffered under the punishments that were poured upon Him and showed His astonishment by stating that God had forsaken Him, leaving Him in His enemies' hands.

To such an extreme as this has the audacity of godless criticism reached in Europe. But all of these opinions melt away and become annihilated before the great work which Christ accomplished, nay which His spirit is still accomplishing after His death. 
Verily when Jesus departed (upon Him be peace) He did not have enough followers true to Him to carry on His mission or to establish His religion. But in the few followers He left behind He put of His own spirit to such an extent that they spread His teaching throughout the world regardless of the consequences as far as they themselves were concerned, whether of persecutions or distresses. For some of them were led before the rulers and commanded to forsake His religion, and when they refused the tormenters and executioners heaped upon them all manner of torture such as eye hath not seen nor ear heard nor hath it entered into the heart of man to conceive. And they died in the midst of these torments in such a state as no one ever died who drowned in the depths of the sea, or was cast in a furnace, or fell from a tower, or was devoured by beasts. The followers of Jesus continued to call men to His faith with steadfast purpose and wonderful perseverance until the world became subject to their principles. All this cannot be explained as a mythical event nor as the result of imagination, for even if at present the principles of His religion have been turned away from the Truth and departed from their originality and now have become subject to dogmas and outward appearances, this is not due to Jesus Himself (upon Whom be peace), but is due to those who usurped authority over His followers.

What was the mission of Jesus to the world? Critics of the Christian religion say that Jesus did not come to men with any new principles nor did $\mathrm{He}$ declare anything new in worship which was not known before, but $\mathrm{He}$ surpassed in one respect in which no other apostle or prophet equalled Him, namely, that He declared openly the nearness of God to His worshippers; for $\mathrm{He}$ made God a father to His creatures, merciful to them, compassionate over them, and made them His sons to enjoy by right all His protection. And He destroyed utterly the iron barriers which had been erected between God and His creatures, and if the leaders of His religion had not opposed these most gracious principles and offices and made themselves mediators between God and His servants, and so reaped for themselves the high offices 
which are not seemly, when we consider the perfection of God and His separation from all secondary causes, then the Jesus Religion would have increased many fold in its power and influence over hearts, and they would not have been compelled in Europe to make a division between the Church and the state, but the religion would have remained in its original purity as long as God wished. However, whatever God wills is sure. The leaders of the Christian religion have taken to themselves the right of mediatorship between God and His creatures, and seized for themselves all the peculiar privileges and control so that they forbade a man to be born or become a Christian or to marry or to pray or to repent or to die, save in the presence of one of themselves. It is perfectly clear that this abrogates the glorious principles which Jesus brought to men, and takes away the one distinction of the Christian faith.

The Christian religion is also a religion of asceticism and of separation from the world as the highest aim. Therefore monasticism has ranked so high in it as one of the perfections, and wealth is considered a cause of God's anger and a separation from His mercy. Another principle of the Christian religion is that evil must not be returned for evil, and that we must not revenge ourselves on the evil doer nor go to law about matters, and that the soul should withdraw itself from everything save God, and the going up into mountains for prayer to God in private and the consecration of life to God's service by asceticism and separation from all things temporal.

[The writer then describes the progress of Christian civilisation, its triumphs in the material world and its failure in many respects in the world of ethics, and concludes his article by trying to show that Mohammed, the Prophet, who came after Jesus, united in His mission the benefits of this world and the next.] So God sent Mohammed (may God bless him and give him peace) as the perfecter of the glorious religious temple which Adam began and which Noah, Abraham, and Moses helped to complete and Jesus adorned and Mohammed perfected. (Upon all of them be prayers and peace).

Mohammed Farid Effendi Wajdi. 